\title{
Intervention Motion Program Of Rhythmic Gymnastics And Its Impact On The Development Of Motor Abilities
}

\author{
Barbora Novotna, MA \\ Michaela Slovakova, MA, PhD \\ Matej Bel University, Faculty of Arts, Department \\ of Physical Education and Sports, Slovakia
}

doi: 10.19044/esj.2016.v12n14p1 URL:http://dx.doi.org/10.19044/esj.2016.v12n14p1

\begin{abstract}
The aim of this study is to present the research results of intervention motion program with rhythmic gymnastics' content on chosen motor abilities of early school age pupils. The program was performed in school within the educational process of physical education. The experiment was realized with selected pupils in the 4th classes at primary schools in Banská Bystrica. The evaluation of motor abilities was realized. Thanks to the chosen standardized tests. The content analysis of motor tests' results show a significant ( $\mathrm{p}<$ 0.01) impact of applied motion program on the level of chosen coordination abilities of pupils with recommendation to the school practice.
\end{abstract}

Keywords: Early school age, intervention motion program, motor abilities, rhythmic gymnastics

\section{Introduction}

The conclusions and results of many researches on the problem of school physical and sport education show a constant decrease in motor fitness and in the physical performance of school population (Bendíková, 2014; Bendíková \& Kostencka, 2013; Hubinák, 2009; Frömel, Novosad \& Svozil, 1999; Mužík \& Krejčí, 1997; and others). Hence, this is the reason various intervention motion programs were implemented in schools. Their realization should result to a change in current state, in the development of the motor fitness, and in the physical performance of school age children. Consequently, the eligibility of intervention motion programs' application has been proven and demonstrated by many researches' results. The "Physical Activity across the Curriculum Program" was realized at schools during a period of three years. Thus, the purpose of the program is to foster the development of physical activity and the reduction of obesity in pupils. 
The results of the program have shown that added subjects in the range of 90 minutes per week with physical activity of medium and high intensity, influences the results and score of daily physical activity and the academic success of the probands (Donelly et al., 2009). Furthermore, the study of Van Beurden et al. (2003) refers to the fact that it is possible to achieve a significant development of the level of basic physical skills. This is achieved by the modification and regulation of the physical education process. However, thanks to the "Move It Groove It" program. They also recommended an increase in the number of lessons instead of an increase in the intensity of physical activities during the physical education. Harrell et al. (1996) examined the impact of the exercise (gym) program on the theoretical knowledge of probands from the nutrition and smoking sphere. The sample consisted of pupils from the $3^{\text {rd }}$ and $4^{\text {th }}$ classes of primary schools. They stated that the pupils of the intervention group achieved significant better results in the knowledge sphere of the impact of physical activity on monitored parameters. The research by Bendíková \& Kostencka (2013) referred to the positive impact of intervention motion program on musculoskeletal system of pupils who were at the $4^{\text {th }}$ classes of primary school. The research was realized within the physical education process. However, the "Bewegte Schule" project proceeded from the German, Austrian, and Swiss knowledge. The main thought of the program was "The school in movement" which was incorporated into schools. The project enables pupils to engage in a specific physical activity when they sit or work with their course books (Mužík \& Krejčí, 1997). The project is famous in Czech Republic under the title "Hejbej se! Nedej se!”. Therefore, it is focused on the development of physical activity in primary schools in the teaching of particular subjects (Gajdošová \& Koštálová, 2006). Its aim is to support health in schools instead of the development and increase in physical activity. The kinaesthetic way of teaching is a part of intervention programs such as: "Ve škole $\mathrm{v}$ pohybu" (School on the move), "Učení v pohybu" (Learning in the movement), and "Celý den $\mathrm{v}$ pohybu" (All day in the movement) (Jonášová, Michálková \& Mužík, 2006). However, all of these physical programs make use of a wide range of physical tools. The rhythmic gymnastics is the tool which is not frequently used to increase and develop the physical activity of early school age pupils. It is the content of one thematic area. This is specifically the Music -rhythm and the dancing activities which is realized within the physical and sport education teaching in Slovak Republic. It focused on the acquisition of competencies in developing basic sensor, motion (physical), intellectual, cultural, artistic and creative abilities, and capacities. All these competencies are developed appropriately according to age. Furthermore, we have to know and apply them appropriately in life and also in sporting activities through cultivated 
and natural movement (ISCED 1). A lot of authors present the opinion that the inclusion of rhythmic gymnastics, music -rhythm, and dancing games has important role to play in the physical education process of early school age pupils. Pupils learn new physical activities which impact their physical and functional development. In addition, they develop the music -rhythm, movement sense, and expressional motion abilities (Trunečková, 2005). Subsequently, the experiment by Slováková (2006) verified the rhythmic gymnastics and dances' program. Thus, the author confirmed the impact of the rhythmic gymnastics and dances on the development of chosen motion abilities of early school age pupils.

Vujovič (2012) monitored the effect of the experimental program of the rhythmic gymnastics on the development of chosen motion abilities of early school age girls in Croatia. Thus, the author noticed positive results. Werner et al. (2012) realized the research in the teaching process which used various motion forms of dance and gymnastics to develop cognitive and affective abilities. They present the need of the active movement which is adapted to specific age group. Palmer Heater (2003) introduced interesting intervention program that is focused on the development of physical condition, fitness, and creativity from the point of view of the rhythmic gymnastics. Therefore, their aim is to unify the music and movement sense with tools and equipment which would enable pupils to develop their creativity too.

\section{Aim}

The aim of this research is to detect and examine the effect of the rhythmic gymnastics on the development of chosen motion abilities of early school age children. The aim proceeded and followed the theoretical background of the study. Then, it developed methodological procedures with consequent application of the exercise program into physical education process.

\section{Hypothesis}

The regular application of rhythmic gymnastics in physical education process will have a positive impact on the development of monitored motor abilities of the early school age children (pupils) in the $4^{\text {th }}$ classes at primary school.

\section{Methods}

The sample consisted of 67 pupils in the 4th classes of a chosen primary school in Banská Bystrica. The experimental group consisted of 33 pupils (EG), while the control group consisted of 34 pupils (CG). Furthermore, the experimental group consisted of 18 girls (age $=9.48$ years 
during input measurements, age $=10.28$ during the output measurements) and 15 boys (age $=9.43$ years during input measurements, age $=10.23$ during the output measurements).

The control group consisted of 18 girls (age $=9.45$ years during input measurements, age $=9.25$ during the output measurements) and 16 boys (age $=9.47$ years during input measurements, age $=9.27$ during the output measurements). The teaching process of the experimental and control group was led by a qualified teacher (M. P.) who has been in the teaching profession for 20 years.

However, we used pedagogical, intentional, field, and two-group experiment as a universal method of the aim of the research. Independent experimental factor was the intervention motion program of the rhythmic gymnastics. Thus, the program was patterned on practical experience and of folk dances, modern dances, and aerobic gymnastics' spheres. Also, thanks to the publication by Trunečková (1993) on "Music -rhythm and dancing games”. Furthermore, this aid was approved by the Ministry of Education of the Slovak Republic under the number 680/2001-41 as the teaching aid and material for schools.

Additionally, we used a set of tests to detect the level of chosen motor abilities. The set was composed of tests according to Moravec et al. (2002) - standing long jump, flamingo balance test, shuttle run 5 x 10 meters. In addition, it include tests according to Měkota \& Blahuš (1983) jump over the pole; and tests according to Vilkner (1982) - run on 3 metres with the turn. Subsequently, we created 20 observing groups from the point of view of the statistics for input data evaluation which were obtained from record protocols. Also, there are values of experimental group and control group of one tested motor ability in each group. One-half corresponds to girls, while another one-half corresponds to boys.

We used unilateral alternative (unilateral paired test, one- sample test) with respect to the fact that we expected improvement in output data instead of deterioration when comparing it with input data.

Also, we used images and tables in results' interpretation. Furthermore, we applied basic logical methods for the analysis, synthesis, comparison, deduction, and the induction of the methods of data evaluation.

In addition, we followed instructions, principles, rules, and recommendations stated by Starší \& Görner (1995) in the use of research method.

\section{Results}

The rhythmic gymnastics' program was an experimental factor which was put and applied into the physical education process of the experimental group once a week during the whole one school year. The program was not 
realized in the physical education process of the control group. However, we realized input and output measurements in order to detect the level of motor abilities. The same test battery was used in both measurements. We can divide the results of particular tested items into several groups. This is done according to the comparison of the mean values from the input and output measurements and realized one-sample paired test. The first item consists of tests in which we monitored and diagnosed the significant improvement in both groups (experimental and control).

Also, we diagnosed explosive leg- muscle strength of lower limbs in standing long jump test. On one hand, we noticed significant improvement in girls' experimental group on statistics' level of 0.01. On the other hand, we also significant improvement in girls' control group on a statistics' level of 0.01 (see fig.1). The difference between the mentioned two girls' groups in the increase of the level of explosive leg- muscle strength of lower limbs was not statistically confirmed. Likewise, the boys' experimental group and the boys' control group achieved the increase and improvement in the monitored motor ability at the same statistics' level of 0.01 . Therefore, the difference between the boys' experimental group and the boys' control group was not significant (see fig.2).

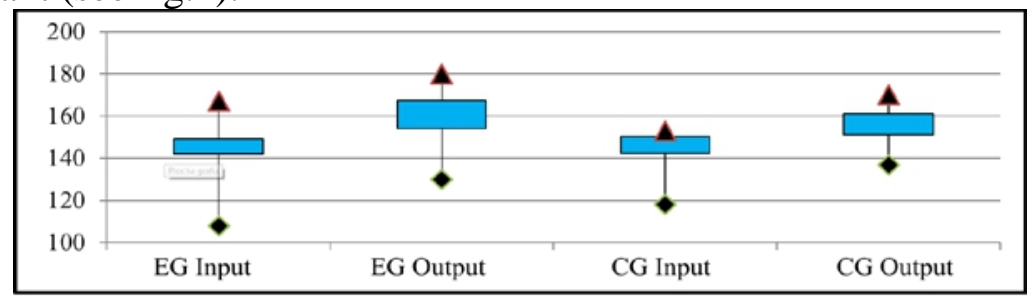

\begin{tabular}{|c|c|c|c|c|c|c|c|c|}
\hline \multirow{2}{*}{$\begin{array}{c}\text { Girls } \\
\text { Test } 1\end{array}$} & \multicolumn{2}{|c|}{ Average } & \multicolumn{2}{|c|}{ Average deviation } & \multicolumn{2}{|c|}{\begin{tabular}{|c|}
$\begin{array}{c}\text { Paired } t- \\
\text { test }\end{array}$ \\
\end{tabular}} & \multirow{2}{*}{ t- test } & \multirow{2}{*}{ F-test } \\
\hline & $E G n=18$ & $\mathrm{CG} n=18$ & EG $n=18$ & $\mathrm{CG} n=18$ & EG & $\mathrm{CG}$ & & \\
\hline Input & 143,06 & 144,18 & 8,80 & 6,61 & \multirow[b]{2}{*}{$* *$} & \multirow[b]{2}{*}{$* *$} & 0,790589 & 0,113043 \\
\hline Output & 158,62 & 156,5 & 9,96 & 6,56 & & & 0.595596 & 0,061564 \\
\hline
\end{tabular}

Figure 1. Statistical evaluation of the changes in the standing long jump test of the girls' experimental and girls' control groups

\begin{tabular}{|c|c|c|c|c|c|c|c|}
\hline 190 & \\
180 & \\
170 & \\
160 \\
150 \\
140
\end{tabular}

Figure 2. Statistical evaluation of the changes in the standing long jump test of the boys' experimental and boys' control groups 
Consequently, we evaluated reaction ability in the run on 3 metres with the turn test. Here, we denoted significant improvement of the level of the monitored ability in the experimental and control groups on the statistics' level of 0.01 (see fig.3). Also, we found a significant difference (on statistics' level of 0.05 ) in the groups' results in favour of the girls' experimental group. Hence, this is the reason we can prove the positive impact of the rhythmic gymnastics' program on the development of reaction ability. The boys' experimental group and the boys' control group also led to the improvement of the level of the reaction level on the statistics' significance level of $1 \%$. Finally, this difference was not statistically significant (see fig.4).

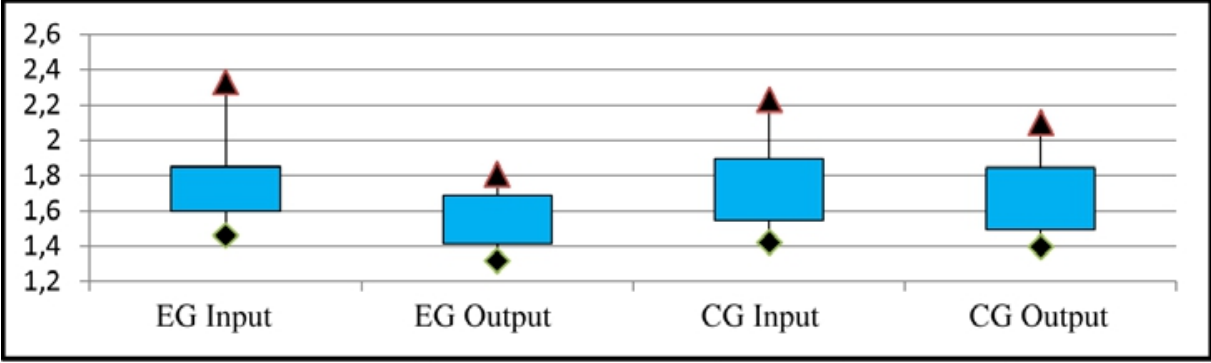

\begin{tabular}{|c|c|c|c|c|c|c|c|c|}
\hline Girls & \multicolumn{2}{|c|}{ Average } & \multicolumn{2}{|c|}{ Average deviation } & \multicolumn{2}{|c|}{$\begin{array}{c}\text { Paired t- } \\
\text { test }\end{array}$} & \multirow{2}{*}{ t- test } & \multirow{2}{*}{ F-test } \\
\cline { 1 - 5 } Test 2 & EG n=18 & CG n=18 & EG n=18 & CG n=18 & EG & CG & & \\
\hline Input & 1,74 & 1,74 & 0,16 & 0,20 & & & 1 & 0,658478 \\
\hline Output & 1,54 & 1,68 & 0,11 & 0,18 & $* *$ & $* *$ & $0,047815^{*}$ & 0,12496 \\
\hline
\end{tabular}

Figure 3. Statistical evaluation of the changes in the run on 3 metres with the turn test of the girls' experimental and girls' control groups

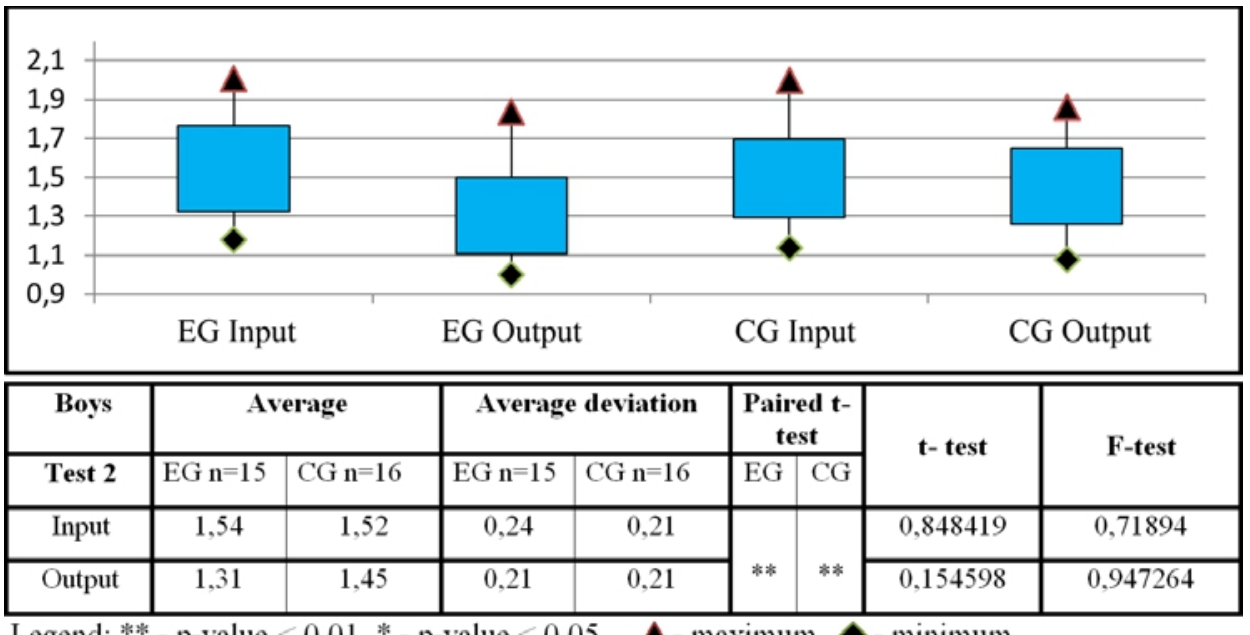

Legend: ** - p-value $<0,01$, * - p-value $<0,05$,

- maximum.

- minimum

Figure 4. Statistical evaluation of the changes in the run on 3 metres with the turn test of the boys' experimental and boys’ control groups 
Consequently, we diagnosed the running speed by the shuttle run $5 \mathrm{x}$ 10 meters test. The improvement was confirmed (on statistical significance level of 1\%) in favour of the girls' experimental and the girls' control groups. However, the significant difference was not detected (see fig.5). The boys' experimental group and the boys' control group also achieved the improvement in monitored motor ability on the statistical significance level of 0.01 . The positive impact of the experimental factor on the development of the running speed in favour of the boys' experimental group was also stated. Here, we confirmed the significant difference on the statistical significance level of 0.05 when comparing it with the control group (see fig. $6)$.

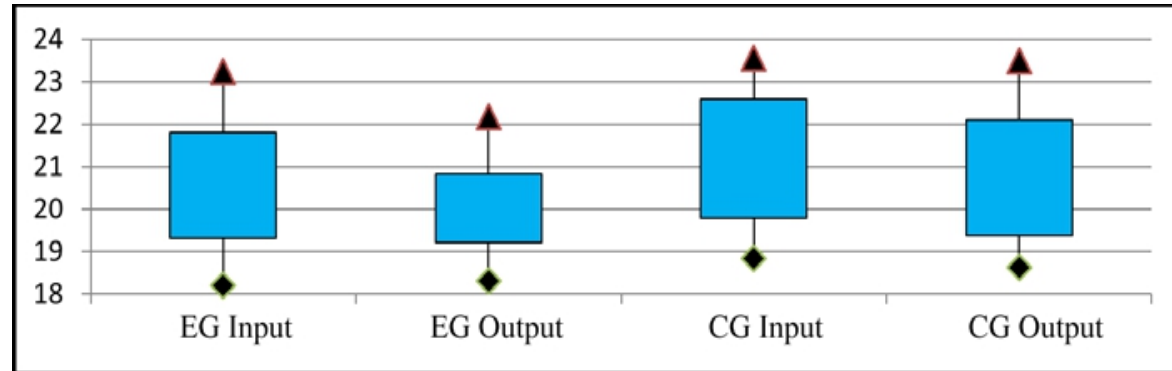

\begin{tabular}{|c|c|c|c|c|c|c|c|c|}
\hline Girls & \multicolumn{2}{|c|}{ Average } & \multicolumn{2}{|c|}{ Average deviation } & \multicolumn{2}{|c|}{$\begin{array}{c}\text { Paired t- } \\
\text { test }\end{array}$} & \multirow{2}{*}{ t- test } & \multirow{2}{*}{ F-test } \\
\hline Test 3 & $\mathrm{EG} n=18$ & $\mathrm{CG} n=18$ & $\mathrm{EG} n=18$ & $\mathrm{CG} n=18$ & EG & $\mathrm{CG}$ & & \\
\hline Input & 20,68 & 21,02 & 1,29 & 1,32 & \multirow[b]{2}{*}{$* *$} & \multirow[b]{2}{*}{ ns } & 0,767808 & 0,956442 \\
\hline Output & 20,11 & 20,60 & 0,88 & 1,33 & & & 0,304908 & 0,222099 \\
\hline
\end{tabular}

Legend: ** - p-value $<0,01,{ }^{*}$ - p-value $<0,05$,

Figure 5. Statistical evaluation of the changes in the shuttle run $5 \times 10$ meters test of the girls’ experimental and girls' control groups

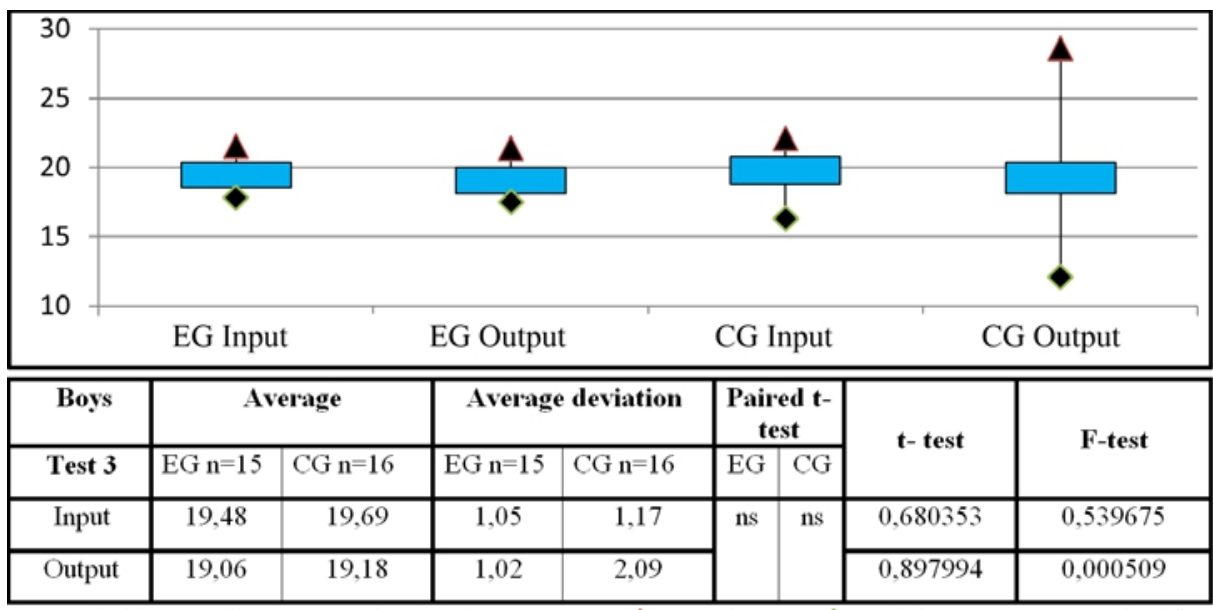

Legend: ${ }^{*}{ }^{*}$ - p-value $<0,01,{ }^{*}$ - p-value $<0,05, \quad \boldsymbol{\Delta}$ - maximum, $\boldsymbol{-}$ - minimum, ns - not significant

Figure 6. Statistical evaluation of the changes in the shuttle run $5 \times 10$ meters test of the boys 'experimental and boys 'control groups 
The gender's difference was proven in the flamingo balance test. Thanks to the evaluation of the static balance. Therefore, the significant difference was found and diagnosed only in the boys' groups. This was in favour of the experimental group on the statistical significance level of $1 \%$, and the control group on the statistical significance level of $5 \%$. The positive impact of the experimental factor was proven with the confirmation of the significant difference between the results of both boys' groups on the statistical significance level of 0.01 in favour of the experimental group (see fig.7, 8).

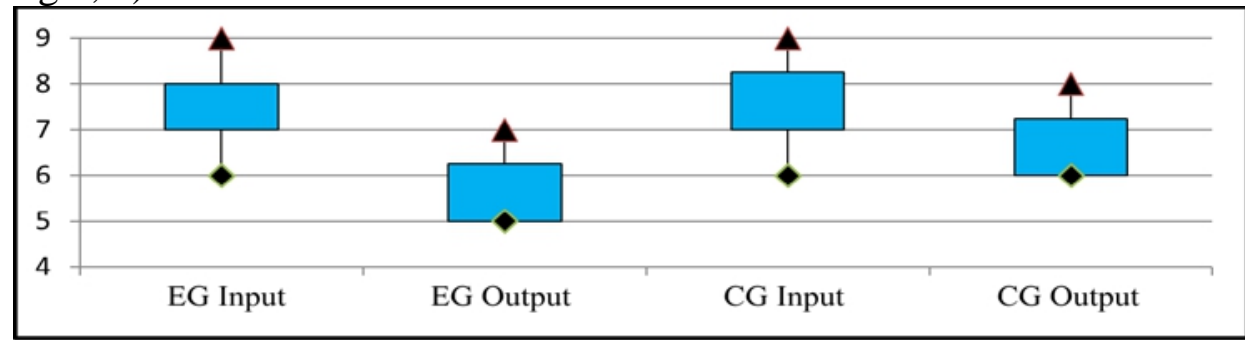

\begin{tabular}{|c|c|c|c|c|c|c|c|c|}
\hline Girls & \multicolumn{2}{|c|}{ Average } & \multicolumn{2}{|c|}{ Average deviation } & \multicolumn{2}{|c|}{$\begin{array}{c}\begin{array}{c}\text { Paired t- } \\
\text { test }\end{array} \\
\end{array}$} & \multirow{2}{*}{ t- test } & \multirow{2}{*}{ F-test } \\
\hline Test 4 & $E G n=18$ & $C G n=18$ & $E G n=18$ & $C G n=18$ & EG & $\mathrm{CG}$ & & \\
\hline Input & 7,56 & 7,75 & 0,68 & 0,78 & \multirow[b]{2}{*}{$* *$} & \multirow[b]{2}{*}{$\mathrm{ns}$} & 0,548742 & 0,609447 \\
\hline Output & 5,93 & 6,93 & 0,58 & 0,58 & & & $0,000952^{* * *}$ & 1 \\
\hline
\end{tabular}

Figure 7. Statistical evaluation of the changes in the flamingo balance test of the girls' experimental and girls' control groups

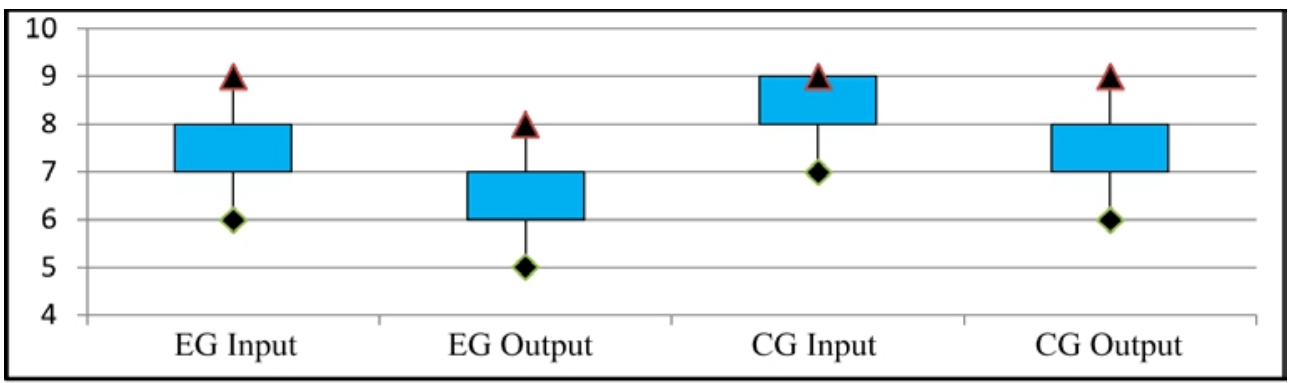

\begin{tabular}{|c|c|c|c|c|c|c|c|c|}
\hline Boys & \multicolumn{2}{|c|}{ Average } & \multicolumn{2}{|c|}{ Average deviation } & \multicolumn{2}{|c|}{\begin{tabular}{|c|}
$\begin{array}{c}\text { Paired t- } \\
\text { test }\end{array}$ \\
\end{tabular}} & \multirow[t]{2}{*}{ t- test } & \multirow[t]{2}{*}{ F-test } \\
\hline Test 4 & $E G n=15$ & $\mathrm{CG} n=16$ & $E G n=15$ & $\mathrm{CG} n=16$ & EG & $\mathrm{CG}$ & & \\
\hline Input & 7,8 & 8,13 & 0,66 & 0,57 & ** & * & 0,266264 & 0,586793 \\
\hline Output & 6,46 & 7,6 & 0,70 & 0,61 & & & $0,000487^{*} * *$ & 0,649753 \\
\hline
\end{tabular}

Legend: * * - p-value $<0,01$, * - p-value $<0,05$,

- maximum,

- minimum,

Figure 8. Statistical evaluation of the changes in the flamingo balance test of the boys' experimental and boys' control groups

Consequently, we verified the complex reaction in the jump over the pole test. The results' difference depends on the gender. The significant 
improvement was noticed only in boys' groups. The statistical significance level of $1 \%$ was diagnosed in the experimental group, while the statistical significance level of $5 \%$ was diagnosed in the control group. The significant difference (on the level of 0.01) was noticed in favour of the experimental group. This is because we found out the positive impact of the rhythmic gymnastics' program on the development of the complex reaction (see fig. 9, 10).

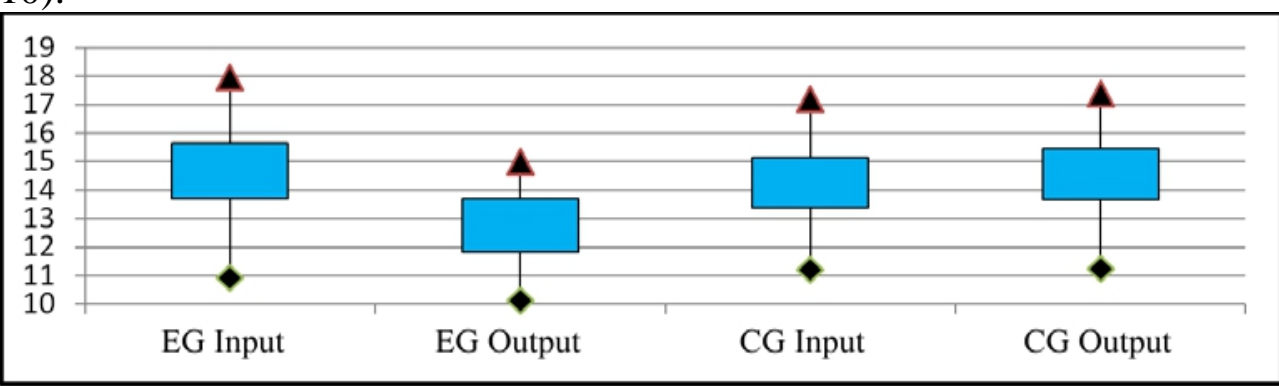

\begin{tabular}{|c|c|c|c|c|c|c|c|c|}
\hline Girls & \multicolumn{2}{|c|}{ Average } & \multicolumn{2}{|c|}{ Average deviation } & \multicolumn{2}{|c|}{\begin{tabular}{|c|}
$\begin{array}{c}\text { Paired t- } \\
\text { test }\end{array}$ \\
\end{tabular}} & \multirow{2}{*}{ t- test } & \multirow[t]{2}{*}{ F-test } \\
\hline Test 5 & $\mathrm{EG} n=18$ & $\mathrm{CG} n=18$ & $\mathrm{EG} n=18$ & $C G n=18$ & EG & $\overline{C G}$ & & \\
\hline Input & 14,35 & 14,28 & 1,45 & 1,24 & \multirow[b]{2}{*}{ ** } & \multirow[b]{2}{*}{ ns } & 0,908521 & 0,578356 \\
\hline Output & 12,69 & 14,36 & 1,18 & 1,21 & & & $0,005142^{* * *}$ & 0,701582 \\
\hline
\end{tabular}

Legend: ** - p-value $<0,01,{ }^{*}$ - p-value $<0,05, \quad \boldsymbol{\Delta}$ - maximum, - minimum, ns - not significant Figure 9. Statistical evaluation of the changes in the jump over the pole test of the girls' experimental and girls’ control groups

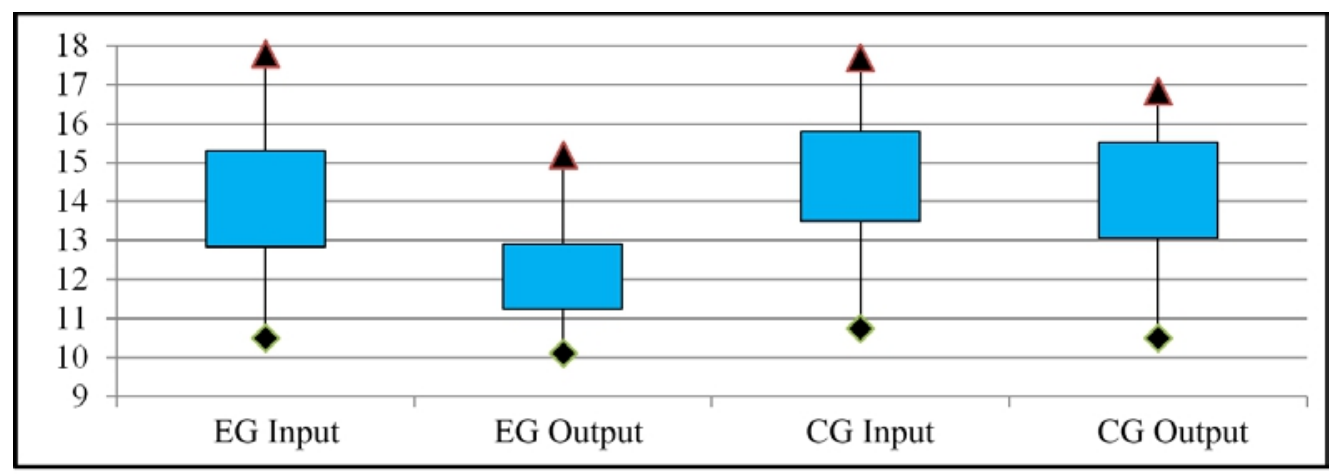

\begin{tabular}{|c|c|c|c|c|c|c|c|c|}
\hline Boys & \multicolumn{2}{|c|}{ Average } & \multicolumn{2}{|c|}{ Average deviation } & \multicolumn{2}{|c|}{\begin{tabular}{|c} 
Paired t- \\
test
\end{tabular}} & \multirow{2}{*}{ t- test } & \multirow{2}{*}{ F-test } \\
\hline Test 5 & $\mathrm{EG} n=15$ & $\mathrm{CG} n=16$ & $\mathrm{EG} n=15$ & $\mathrm{CG} n=16$ & EG & $\overline{\mathrm{CG}}$ & & \\
\hline Input & 14,10 & 14,43 & 1,67 & 1,43 & *** & * & 0,650031 & 0,382356 \\
\hline Output & 12,22 & 14,14 & 1,09 & 1,40 & & & $0,002904 * *$ & 0,440472 \\
\hline
\end{tabular}

Legend: ** - p-value $<0,01,{ }^{*}$ - p-value $<0,05, \quad \boldsymbol{\Delta}$-maximum, $\boldsymbol{\nabla}$ - minimum,

Figure 10. Statistical evaluation of the changes in the jump over the pole test of the boys' experimental and boys' control groups 


\section{Conclusion}

In conclusion, the results of the monitored experiment refer to a positive effect of the development of monitored motor abilities. The positive effect was achieved by the regular application of the rhythmic gymnastics' program during one school year. Thus, our results confirmed the stated hypothesis. The development of motor abilities depends on the sex which is expressed in the different structure of the significant differences. This difference is between the experimental samples in favour and benefit of the experimental group. Consequently, it is stated that the realized experiment had favourable and positive impact on significant improvement of girls in following motor abilities:

- Reaction ability

- $\quad$ Complex reaction ability

- $\quad$ Ability of static balance

On the other hand, the realized experiment had favourable and positive impact on the significant improvement of boys in following motor abilities:

- $\quad$ Complex reaction ability

- $\quad$ Ability of static balance

- $\quad$ Running speed

However, the results of this study show the positive impact of the intervention motion program which contained the rhythmic gymnastics' tools and procedures. Also, this program is effective. Thus, we hereby recommend that it should be integrated into the physical education process.

\section{References:}

Bendíková (2014). Lifestyle, physical and sports education and health benefits of physical activity. In European researcher: international multidisciplinary journal. - Sochi: Academic publishing house Researcher, 2014. - ISSN 2219-8229. - Vol. 69, no. 2-2 (2014), pp. 343-348.

Bendíková \& Kostencka (2013). Exercise routine as a conditions of early school age pupils' health: [scientific monograph]. 1. vyd. Bydgoszcz: Oficyna Wydawnicza Mirosław Wrocławski, 2013. - 149 s. ISBN 978-8362611-56-0.

Donnelly et al. (2009). Physical Activity Across the Curriculum (PAAC): A randomized controlled trial to promote physical activity and diminish overweight and obesity in elementary school children. Preventive Medicine. Volume 49, Issue 4, October 2009. s. 336-341. ISSN 0091-7435. [cit. 2015.12.14] Available on the internet: http://www.sciencedirect.com/science/article/pii/S0091743509003557. 
Frőmel, Novosad \& Svozil (1999). Pohybová aktivita a sportovní záujmy mládeže. Olomouc : Fakulta tělesné kultúry, Univerzita Palackého v Olomouci, 1999. 173 s. ISBN 80 - $7067-945$ - X.

Gajdošová \& Koštálová (2006). Hejbej se! Nedej se! edukační materiál pro učitele ZŠ s pohybovými aktivitami do vyučovaní a pracovními listy pro děti. [online]. [cit 2015-08-22]. dostupné na internete: https://is.muni.cz ISCED 1 - telesná výchova. [cit. 2015.12.14] Available on the internet:http://www.statpedu.sk/sites/default/files/dokumenty/inovovanystatny-vzdelavaciprogram/telesna\%20a\%20sportova\%20vychova_pv_2014.pdf.

Hubinák (2009). Potreba pohybu žiaka v školskom prostredí počas prestávky - In: Disputationes Scientificae Universitatis Catholicae in Ružomberok. ISSN 1335-9185, Roč. 9, č. 1 (2009), s. 55-58.

Harrell (1996). Effects of a school-based intervention to reduce cardiovascular disease risk factors in elementary-school children: The Cardiovascular Health in Children (CHIC) Study. The Journal of Pediatrics, Volume 128, Issue 6, June 1996. s. 797-805. ISSN 0022-3476. [cit. 2015.12.14] Available on the internet:http://www.sciencedirect.com/science/article/pii/S002234769670332 3.

Jonášová, Michálková \& Mužík (2006). Učení v pohybu aneb výuka pro neposedy. Brno : Masarykova univerzita, Pedagogická fakulta, 2006. ISBN: 80-210-4074-2.

Měkota \& Blahuš (1983). Motorické testy v tělesné výchově. Praha : SPN, 1983, 336 s.

Moravec et al. (2002). Eurofit. Telesný rozvoj a pohybová výkonnost' školskej populácie na Slovensku. Bratislava : SVSTVŠ, 2002. Druhé vydanie. ISBN 80-89075-11-8.

Mužík \& Krejčí (1997). Tělesná výchova a zdraví. 1. vyd. Olomouc : HANEX. 1997. 139s. ISBN 80-85783-17-7.

Palmer Heather (2003). Teaching Rhythmic Gymnastics: A Developmentally Appropriate Approach. Human Kinetics 2003, p.131. ISBN 0736042423.

Slováková (2006). Rytmická gymnastika a tanec ako prostriedok rozvíjania vybraných pohybových schopností detí mladšieho školského veku. Dizertačná práca. Univerzita Mateja Bela v Banskej Bystrici, Pedagogická fakulta, Katedra telesnej výchovy, 2006. Nepublikované.

Starší \& Görner (1995). Vedeckovýskumná práca v telesnej výchove a športe. Banská Bystrica : UMB FHV KTVŠ, 1995, 84 s. ISBN 80-85162-881.

Trunečková (1993). Hudobno-tanečné hry. Banská Bystrica: Brummer a Brummer, 1993. 73 s. ISBN 80-900443-3-3-6. 
Trunečková (2005). Hudobno - pohybová edukácia na základných školách. Banská Bystrica : PF UMB, 2005, 76 s. ISBN 80-8083-042-8.

Van Beurden (2003). Can we skill and activate children through primary school physical education lessons? "move it groove it"-a collaborative health promotion intervention. Preventive Medicine, Volume 36, Issue 4, April 2003. s. 493-501. ISSN 0091-7435. [cit. 2015.12.14 Available on the internet:http://www.sciencedirect.com/science/article/pii/S009174350200044 0 .

Vilkner (1982). Untersuchungsmetodik zur Diagnostik der motorischen Reaktionsfahigkeit. Theor. Prax Korperkult. 3, 1982, s. 197-205.

Vujović (2012). The influence of Rhythmic gymnastics teaching contents upon development of some motor skills among the schoolgirls od the fifth grade of primary school. In.: Sport Mont sep. 2012, Issue 34-36, p 482, 6p. ISSN 14517485.

Werner et al. (2012). Teaching Children gymnastics, third edition. Copyright 2012, 264 p. ISBN -13: 9781450410922. 